\title{
Transferability of Laboratory Fracture Data to Safety Assessment of Postulated Defects in Critical NPP Components
}

\author{
N. Taylor and K. F. Nilsson
}

Joint Research Centre of the European Commission, Institute for Energy, Petten, the Netherlands

удК 539.4

\section{Применимость результатов экспериментальных исследований на трещиностойкость для оценки прочности ответственных узлов AЭC}

\section{Н. Тейлор, К. Ф. Нилссон}

Объединенный исследовательский центр Европейской комиссии, Энергетический институт, Петтен, Нидерланды

С иелью оценки прочности корпусов реакторов АЭС проведены натурные стендовые испьтания на трециностойкость образиов с внутренними дефектами. Представленные резульmаты свидетельствуют о возможности использования в расчетах полученнызх стандартнылх данных для обнаруженных и предполагаемых дефектов корпусных сталей. Показано, что применение метода "Master Cигvе" обеспечивает более точное прогнозирование условий вязкохрупкого перехода, чем подходы, использующие характеристику $K_{I c}$ в зависимости om $R T_{N D T}$.

Ключевые слова: конструкционная целостность, механика разрушения, стендовое испытание, "Master Curve".

Introduction. Dealing with real or postulated cracks in large structures is a classical engineering problem, which takes on special significance for components in nuclear power plants. While regulators, utilities, and plant manufacturers have developed effective procedures to assess structural integrity, a policy of continuous development is required to ensure that safety margins are maintained as the plants accumulate many years of service. Measurement of fracture toughness parameters on compact laboratory specimens plays a key role in this process, and there is now wide acceptance of methods such as Master Curve to assess shifts in the transition behavior from as-received to end-of-life states. However, there remain obstacles to the application of such laboratory-generated representations of the fracture transition behavior for assessing postulated defects in critical components such as reactor pressure vessels, the so-called transferability factors:

- Constraint due to geometry

- Constraint due to loading

- Crack front size (cleavage site sampling effect)

- Representativeness of materials data and fracture mode consistency 
- Local variations and/or gradients in material properties

- Environment.

Transferability has been addressed by several projects organized by the Network for Evaluation of Structural Components (NESC). The NESC is an international network operated by the European Commission's Joint Research Center to verify the overall structural integrity assessment process using large-scale experimental projects, designed as benchmarks. The NESC has four major projects: NESC-I, the spinning cylinder pressurized thermal shock (PTS) test was completed in 2000. In NESC-II, two PTS tests on cylinders with shallow cracks were completed in 1999. NESC-III concerns a large-scale test on a dissimilar weld pipe assembly performed in February 2003. The NESC-IV project completed a test series on defect-containing beams in 2002. This paper focuses on the consideration given to transferability issues for RPV flaws in the NESC-I, II and IV projects.

Pressurized Thermal Shock (PTS) Tests. A characteristic feature of PTS simulations is that the highest probability for defect extension is in the near-surface region, where its assessment is complicated by the variation of the material and fracture toughness properties, the HAZ size, the loss of the defect-tip constraint, warm prestressing effects, and clad residual stresses. The first NESC project [1] centered on the spinning cylinder experiment conducted at the AEA Technology, UK, and was designed to simulate the conditions associated with an aging flawed RPV. The test piece was an internally clad 7-ton steel cylinder into which a total of 18 defects, differing widely in fabrication method, size, and location, were introduced. During the test, it was subject to mechanical loads due to high-speed rotation and thermal shock loads resulting from a cold-water quench directed at the inner surface of the heated cylinder (Fig. 1). For the fracture analysts it posed a special challenge both a) in the test design stage, to ensure a combination of defect size, material condition, and loading that would produce crack initiation and $b$ ) in the post-test analysis phase, to assess the observed behavior of the defects in greater detail. The test was successfully performed in March 1997 and realized the planned cleavage run-and-arrest event at one end of a large through-clad defect. Although the defect growth also occurred at the large sub-clad crack as planned, the expected cleavage event failed to materialize.

In the post-test analysis, the Master Curve approach (which had been calibrated in an extensive material characterization program) provided a useful tool for assessing the sensitivity to the analysis parameters via comparison of the probability of cleavage for the given values of the crack-tip driving force and temperature (Table 1). The best estimate of 0.97 was obtained using a 3-D cracked body analysis to determine $K_{J}$ and applying the Master Curve function derived from a deep notch, i.e., high constraint specimens. The use of low constraint shallow notch data reduces the failure probability. However, the detailed analysis [2] of the local constraint conditions indicates that, at this depth, small-scale yielding conditions should prevail (Fig. 2). Hence, the higher constraint data are appropriate for the assessment of the aforementioned crack front region. This 0.97 level is above that, at which a cleavage event could be reasonably expected in a single test, implying that this analysis technique is still 
somewhat pessimistic. Simpler engineering methods provided even more pessimistic predictions of the crack driving force and hence even higher probabilities of cleavage. A coupled cleavage-ductile local approach formulation with a 3-D elastic-plastic finite-element model was also applied [3]. The observed time of the cleavage event corresponded well to the maximum predicted cleavage probability, although the extent of ductile tearing was underestimated.

$\mathrm{T}$ a $\mathrm{b} 1$ e 1

NESC-I Spinning Cylinder Tests: Probability of Cleavage in the Near-Surface Base Material Region for a Large Through-Clad Defect at the 217th s of the PTS Transient

\begin{tabular}{|c|l|c|c|}
\hline No. & \multicolumn{1}{|c|}{ Analysis Type } & $\begin{array}{c}K_{J} \text { at } 217 \mathrm{~s} \\
\mathrm{MPa} \sqrt{\mathrm{m}}\end{array}$ & $\begin{array}{c}\text { Probability } \\
\text { of cleavage }\end{array}$ \\
\hline 1 & PD6493 & 420 & 1.0 \\
\hline 2 & 2-D FE + weight function & 350 & 0.999996 \\
\hline 3 & 2-D FE + weight function + reduced residual stress & 320 & 0.9999 \\
\hline 4 & R6 Appendix 4 & 310 & 0.9996 \\
\hline 5 & $\begin{array}{l}\text { 3-D elastoplastic FE analysis: high constraint } \\
\text { (a/W = 0.5) data, standard crack-front normalizing } \\
\text { parameter (25 mm) }\end{array}$ & 260 & 0.97 \\
\hline 6 & 3-D FE analysis with low constraint toughness data & 260 & 0.23 \\
\hline 7 & $\begin{array}{l}\text { 3-D FE analysis with a reduced Master Curve crack } \\
\text { front normalizing parameter (10 mm) }\end{array}$ & 260 & 0.77 \\
\hline
\end{tabular}

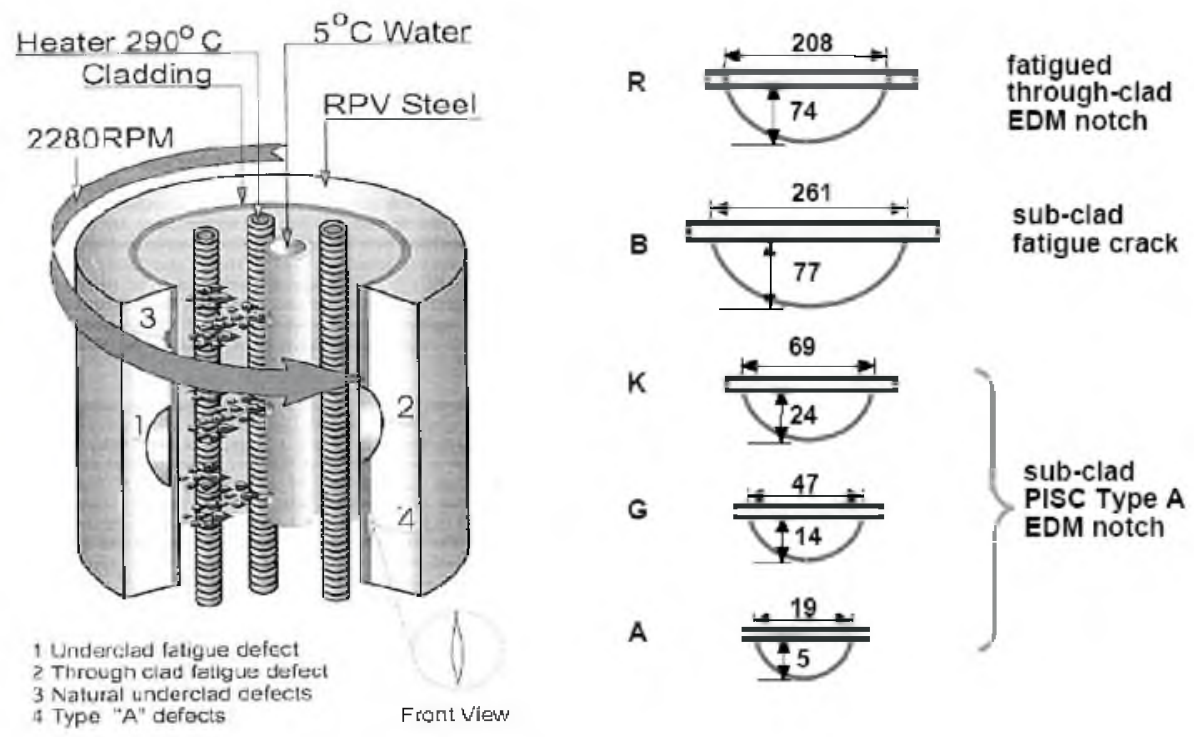

Fig. 1. NESC-I component and the principal defects considered in fracture assessment.

The NESC-II project considered two large-scale PTS tests performed at MPA Stuttgart [4]. The test pieces were thick-walled cylinders with an outer diameter of $800 \mathrm{~mm}$ and wall thickness of $190 \mathrm{~mm}$, fabricated of $17 \mathrm{MoV} 84 \bmod$ steel 
with a two-layer austenitic cladding on the internal surface. The NP2 test piece, containing a fully circumferential sub-clad defect with a depth of $8 \mathrm{~mm}$, produced an intergranular crack growth event; with a maximum extension of approximately $15 \mathrm{~mm}$. In the case of the NP1 test piece containing two shallow semi-elliptical through-clad defects of depth $21 \mathrm{~mm}$ and length $60 \mathrm{~mm}$, the planned loading transient was achieved but no growth occurred. While the results of the two tests underline the inherent conservatism of the existing defect assessment procedures for shallow RPV flaws, the absence of the desired cleavage event shows that the transferability issues (interpretation of material test data and quantifying the effects of crack front length and constraint loss effects) have not been sufficiently resolved.

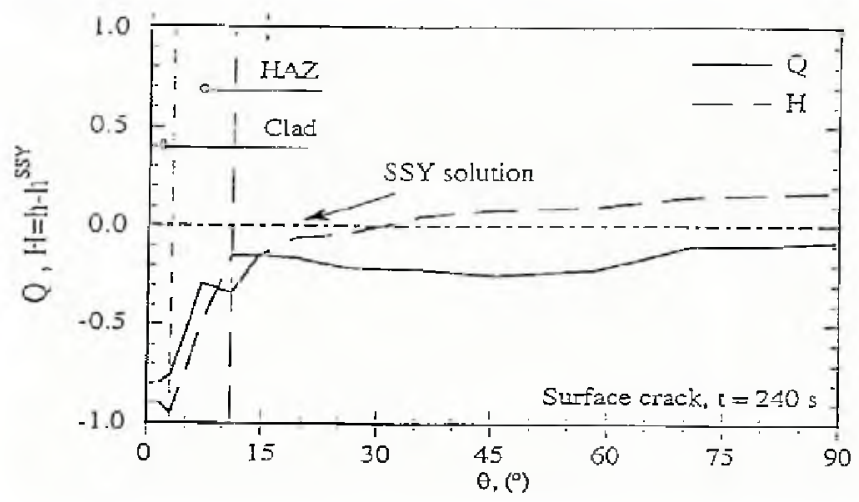

Fig. 2. Variation of constraint parameters $H$ and $Q$ along the boundary of a large through-clad defect, showing the area of loss of constraint close to the surface.

Isothermal Tests on Biaxially-Loaded Beams. The NESC-IV project is a focussed experimental/analytical program for the assessment of an RPV shallow flaw. Two series of benchmark tests [5] have been performed at the ORNL facility in the US. In Part A, six clad cruciform specimens (Fig. 3) containing shallow surface-breaking flaws located in the weld material were successfully tested. For Part B, further four beam tests were performed using an innovative test piece design with a simulated embedded flaw. The material used was removed from a production-quality RPV that had never been put in service, hence representing a start-of-life condition $\left(T_{0}\right.$ for the weld is $\left.-88^{\circ} \mathrm{C}\right)$. The European partners have contributed with extensive material characterization testing using standard $\mathrm{C}(\mathrm{T})$ $25 \mathrm{~mm}$ specimen geometry and $10 \times 10 \mathrm{~mm} \mathrm{SE}(\mathrm{B})$ bend bars, as well as pre-test calculations to select an appropriate test temperature in the lower transition region. Figure 4 shows provisional results together with the Master Curve from standard fracture deep-notch testing. The data for both test series have been size corrected to a $25 \mathrm{~mm}$ crack front as per ASTM E1921.

Detailed FE analysis has shown that, in the uniaxially loaded beams, the near-surface crack tip encounters a low constraint situation (Table 2), and this correlates with the fact that in the transition regime the data points lie above the Master Curve. Table 2 also indicates that biaxially loaded cruciform beams present a high constraint situation. Although the standard Master Curve should be appropriate, the tests appear to have produced lower stress intensities than expected at fracture. 
$\mathrm{T}$ a b 1 e 2

$Q$-Values Evaluated at $r /\left(Y / \sigma_{Y}\right)=\mathbf{2 . 0}$ for a NESC-IV Cruciform Specimen (Biaxial Bending) and an Embedded Flaw Specimen (Uniaxial Bending)

\begin{tabular}{|c|c|c|}
\hline Specimen type & Case & $Q$ \\
\hline Single-edge notch bend beam specimen SE(B) & $a / W=0.50$ & +0.05 \\
& $a / W=0.20$ & -0.34 \\
& $a / W=0.10$ & -0.68 \\
\hline Semi-elliptical defect under biaxial-loading & deepest point & -0.20 \\
& HAZ & -0.05 \\
\hline Embedded flaw under uniaxial bending & deep tip & -0.35 \\
& shallow tip & -1.05 \\
\hline
\end{tabular}

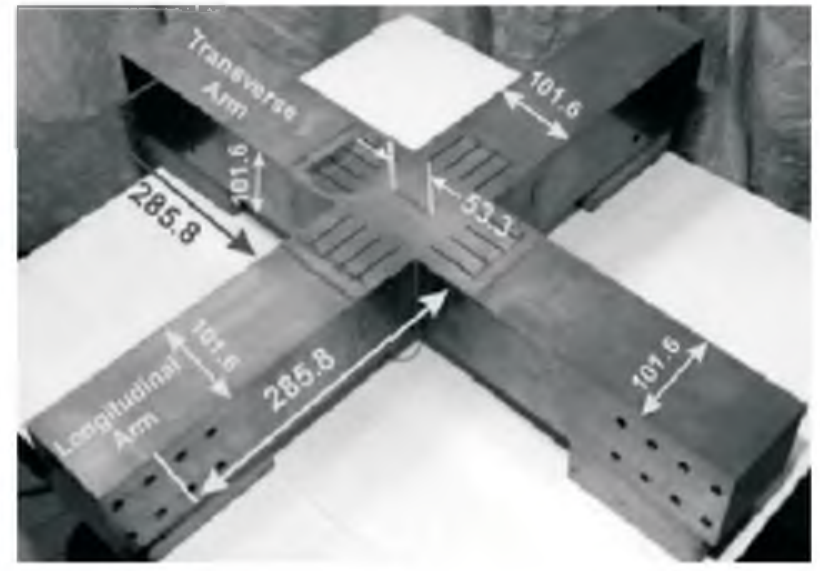

Fig. 3. The ORNL cruciform beam design used for the NESC-IV tests.

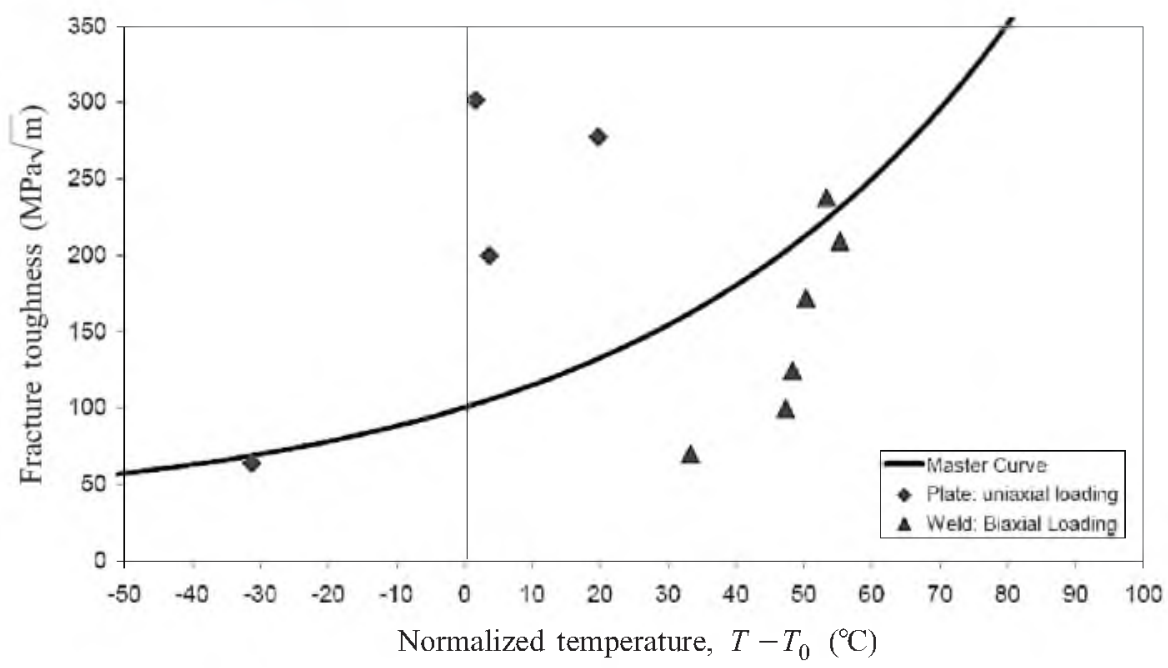

Fig. 4. Data (crack front size-corrected to $25 \mathrm{~mm}$ ) from the biaxial and uniaxial bend tests compared with the Master Curve for deep notch specimens.

Detailed post-test fracture analyses are now in progress, including the application of a Weibull stress model, which was used successfully for predicted biaxial effects in previous ORNL test series [6]. This work is being done in close 
collaboration with the VOCALIST shared cost action project (Validation of Constraint-Based Methodology in Structural Integrity) [7]. In particular, it is intended that the results will contribute to the VOCALIST "Best Practice Handbook for Application of Constraint-Based Procedures in Structural Integrity Assessment" [8].

\section{Conclusions}

1. Large-scale experimental benchmarks have a key role to play in assessing transferability issues. The NESC network projects aim to address this need.

2. The Master Curve approach provides reliable and less conservative estimates of fracture events than taking $K_{\mathrm{Ic}}$ as a function of $R T_{\mathrm{NDT}}$. Local approaches show promise, but are complex to calibrate and apply.

3. Treatment of biaxial loading effects and crack front size adjustment is still under investigation, to provide a better basis for deciding if additional safety margins exist from constraint-loss effects.

Acknowledgements. The authors greatly acknowledge the contributions from all the Network partners, in particular, Steering Committee members and their organizations, as well as the support from the Joint Research Center of the European Commission.

\section{Резюме}

Із метою оцінки міцності корпусів реакторів AEC проведено натурні стендові випробування на тріщиностійкість зразків із внутрішніми дефектами. Представлені результати свідчать про можливість використання в розрахунках отриманих стандартних даних для виявлених дефектів корпусних сталей та прогнозованих. Показано, що метод "Master Curve" забезпечує більш точне прогнозування умов в'язкокрихкого переходу, ніж підходи, в яких використовується характеристика $K_{\mathrm{Ic}}$ в залежності від $R T_{\mathrm{NDT}}$.

1. B. R. Bass, J. Wintle, R. Hurst, and N. Taylor, NESC-1 Project Overview, European Commission, EN 19051.

2. I. Sattari-Far et al., A Sensitivity Study on the Fracture Analysis of the NESC-1 Spinning Cylinder Experiment, NESCDOC TG3 (99) 09.

3. A. H. Sherry et al., "The application of Local Approach to predict the outcome of the NESC experiment," ASME PVP, 365, 75-84 (1998).

4. L. Stumpfrock, D. I. Swan, D. Siegele, et al., NESC-II Final Report-Brittle Crack Initiation, Propagation and Arrest of Shallow Cracks in a Clad Vessel under PTS Loading, NESCMAN (02) 07, Report EUR 20696 EN (2003).

5. N. Taylor and B. R. Bass, "Overview of NESC-IV cruciform specimen test results," in: ASME PVP Conf. (August 2002), Vancouver, Canada (2002).

6. B. R. Bass, W. J. McAfee, P. T. Williams, and W. E. Pennell, "Fracture assessment of shallow-flaw cruciform beams tested under uniaxial and biaxial loading conditions," Nucl. Eng. Design, 188, No. 3, 259-288 (1999). 
7. D. Lidbury et al., "VOCALIST - an international program for the validation of constraint-based methodology in structural integrity," in: Proc. ICONE 9 , Paper 722 .

8. K. F. Nilsson et al., "Validation of constraint-based methodology in structural integrity: best practice handbook," in: ASME PVP Conf. (August 2002), Vancouver, Canada (2002).

Received 26. 05. 2003 